\title{
Life Quality Investments and Environmental Damage Decreasing in Coal Mining Regions
}

\author{
Lyudmila Sagdeeva ${ }^{1}$, Lyudmila Starikova ${ }^{2, *}$, and Irina Trapeznikova ${ }^{1}$ \\ ${ }^{1}$ Kemerovo State University, 650000, 6 Krasnaya St., Kemerovo, Russia \\ ${ }^{2}$ Plekhanov Russian University of Economics, Kemerovo branch, 650992, 39, Kuznetskiy prospect, \\ Kemerovo, Russia
}

\begin{abstract}
The industrialized Kuzbass (Kemerovo Region, Russia) is not only a source of raw materials for the planet, but also a manufacturer of ferrous and non-ferrous metals and chemical products. Since 1990s, the "lungs of the planet" - Siberian taiga - has been actively cut down, and mining and processing enterprises are being built. A large part of the territory of Kuzbass is exposed to a strong technogenic impact. The consequence of the irreversible process of destruction and degradation of soil under industrial waste dumps during open-pit mining of coal, pollution of groundwater and surface water, atmospheric pollution by industrial emissions is the disappearance of natural flora and fauna, as well as the catastrophic threat to the health of people living in the region. Only $30 \%$ of the territory of the region, where $5-10 \%$ of the population lives, correspond to satisfactory environmental conditions. The article discusses the problems of anthropogenic pressure and environmental capacity of the territory on the example of the Kemerovo region, attempts to assess damage to land resources in the Kemerovo region on the example of 2017, based on the standard methodology for assessing the need for investment in environmental protection.
\end{abstract}

\section{Introduction}

The 20th century brought to humanity a lot of benefits associated with the rapid development of science and industry. However, it also put the Earth on the verge of ecological catastrophe. Intensification of the extraction and use of natural resources, urbanization and huge volumes of harmful emissions, are changing the nature. Their wide distribution has led to such interaction of nature and man, when the anthropogenic load exceeds the ecological capabilities of a given territory, mainly due to the potential of its natural resources and the overall sustainability of natural landscapes to the impacts of human activity.

The development strategy of the Kuzbass (the largest coal basin in Russia) provides for the growth of annual coal production by 2035 by 128.5 million tons, which is $53 \%$ of 2017 annual production. The main focus is on the development of underground coal mining is the increase by $90 \%$ by 2035 . The level of open pit mining is going to be stabilized at 210 million tons per year.

\footnotetext{
*Corresponding author: $\underline{\ln 55 @ \text { list.ru }}$
} 
Each additional million tons of coal mined in the region increases gross emissions into the atmosphere by about 10 thousand tons, and gives about 7 million tons of different waste disposed in the region [1].

\section{Materials and Methods}

The underestimation of the environmental factor leads to a distortion of the indicators of the regional economic development. Of 95 thousand $\mathrm{km}^{2}$ of Kemerovo region territory, coalbearing sediments occupy about 26.7 thousand $\mathrm{km}$. At the same time, the data of regional statistics may be distorted, since there is too much variation between the annual data on the volume of disturbed lands. Apparently, there is no possibility to make accurate measurements of disturbed areas, and the roughly calculated data are given. Taking into account this reality, it can be argued with a high degree of probability that about a third of the region's territory (this is mainly the western and southern parts of it) is accompanied by more serious environmental problems, then it is reflected in official data (Table 1 [2]).

Table 1. Volumes of environmental pollution in Kuzbass (Kemerovo region) in the period 2002 2017.

\begin{tabular}{|c|c|c|c|c|c|c|c|c|}
\hline Years & 2002 & 2007 & 2010 & 2012 & 2014 & 2015 & 2016 & 2017 \\
\hline $\begin{array}{l}\text { Disturbed land. } \\
\text { total area, } \\
\text { thousand hectares }\end{array}$ & 64.74 & 66.3 & 62.1 & 58.65 & 58.05 & 35.80 & 98.09 & 102 \\
\hline $\begin{array}{l}\text { Reclaimed land in } \\
\text { the current year, } \\
\text { thousand hectares }\end{array}$ & & & $\begin{array}{l}\text { no } \\
\text { data }\end{array}$ & 0.92 & & 0.73 & $\begin{array}{l}\text { no } \\
\text { data }\end{array}$ & \\
\hline $\begin{array}{c}\text { The volume of } \\
\text { waste, million tons }\end{array}$ & & & & & & & & \\
\hline $\begin{array}{l}\text { Emissions to the } \\
\text { atmosphere, } \\
\text { thousand tons }\end{array}$ & & & & & & & & 1718.8 \\
\hline $\begin{array}{l}\text { Discharges into } \\
\text { surface water } \\
\text { bodies, million } \mathrm{m}^{3}\end{array}$ & & & & & & & & \\
\hline
\end{tabular}

One of the most significant environmental aspects is the disturbance of the earth's surface. Since the beginning of mining operations in Kuzbass, over 55 thousand hectares were broken by open pits, and more than 35 thousand hectares by mines, in total about 102 thousand hectares were disturbed (as on January 01, 2018) and this is without taking into account the influence of enterprises on the adjacent territories. Therefore, more than 582 hectares of land requiring the reclamation are left from the closed mining enterprises, including land occupied by sludge-diggers, waste and tailing dumps.

The disturbed lands, even without taking into account the spread of mud on the adjacent territories, constitute one fourth of all residential lands and exceed the lands occupied by rural development. The area of disturbed land in the Kemerovo Region is 10 times more than the average in Russia [3-4].

In general, 1741 thousand hectares $(34.8 \%)$ were worked out from the total area of disturbed lands. This does not even compensate for the territories newly allocated for coal mining. Regional statistics show that a steady change in agricultural land is decreasing. In 2017 , 4.7 thousand hectares of agricultural land was rejected in the Kemerovo region.

Distribution of the area of disturbed land in the main coal basins of the Russian Federation 
in 2017 is shown in Fig. 1 [2]. The share of disturbed land in the Kemerovo Region is less than $1 \%$, but the situation is complicated by the fact that most of the region's territory $(60 \%)$ is mountain formations and the main anthropogenic load is formed on the flat part of the Kuznetsk Basin and the south of the West Siberian Lowland. Thus, almost 17\% of the flat part of the Kemerovo region is disturbed land. Geographically, they coincide not only with deposits of hard coal, but also the main agricultural zone of the region with highly productive soils.

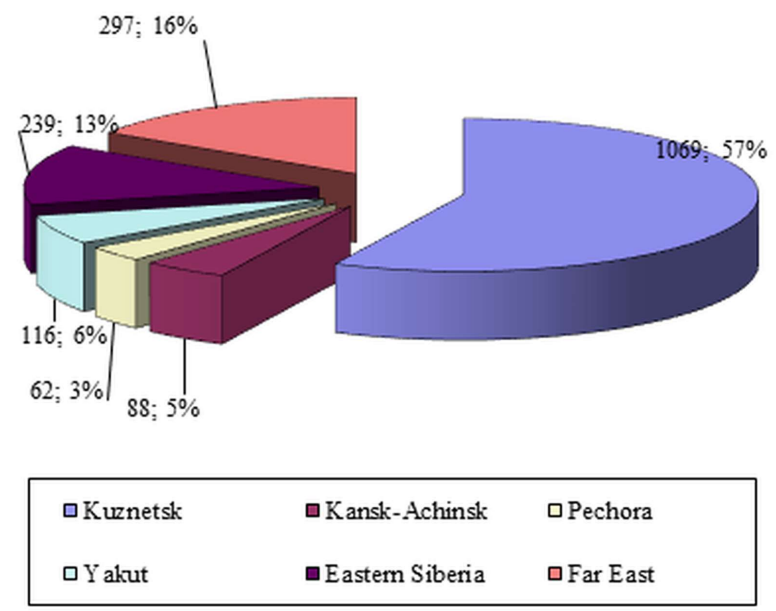

Fig. 1. Distribution of disturbed land area by main coal basins in 2017 , hectares.

In addition to open-pit mining, the cause of the anthropogenic environmental impact of the coal industry is the formation and disposal of production waste. The volume of formation of solid waste in the coal industry in recent years has been steadily increasing, mainly due to an increase in production volumes and an increase in the share of the open-pit method of coal mining. Figure 2 shows a comparative analysis of the volume of waste generated in the coal regions of the Russian Federation in 2017. $81 \%$ is the share of the Kuznetsk coal basin (Kuzbass) [2].

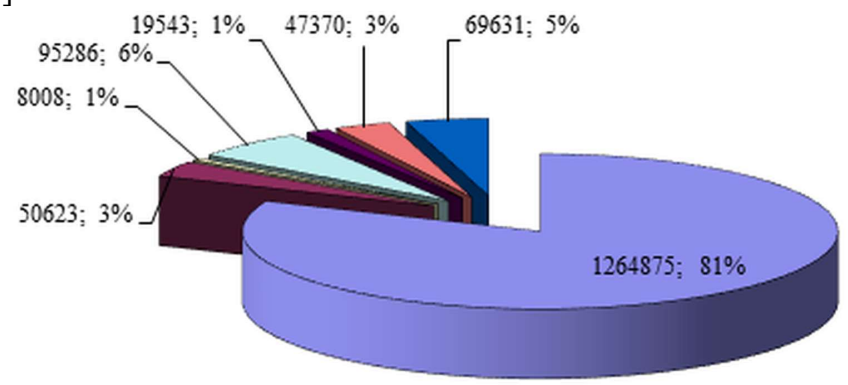

\begin{tabular}{|c|c|c|}
\hline $\begin{array}{l}\text { QKuznetsk } \\
\text { Urals }\end{array}$ & $\begin{array}{l}\square \text { Kansk-Achinsk } \square \text { Pechora } \\
\square \text { Eastern Siberia } \square \text { Far East }\end{array}$ & 口Yakut \\
\hline
\end{tabular}

Fig. 2. The volume of waste produced by coal regions, thousand tons.

According to quantitative estimates, the total volume of accumulated solid waste of all 
types in the Kemerovo Region is 4 billion tons. The share of the coal industry in the total waste generated by the main industries in 2017 is $95 \%$ (3.12 billion tons). Some of them are hazardous waste. These include any substances with flammable properties, corrosiveness (high acid or high alkaline), instability (which emit fumes that can explode) and toxicity. By mass, the share of the 1 st hazard class waste accounts for about $0.001 \%$, the 2 nd one $0.006 \%$, the $3 \mathrm{rd}$ one $-0.002 \%$, the 4 th one $-1.55 \%$, and the 5 th one $-98.44 \%$.

Overburden and host rocks are usually stored in dumps. Storage of rocks in dumps is accompanied by such negative consequences as air pollution by rock and coal dust, and during self-ignition of rocks - by harmful gases (oxides of carbon, sulfur, nitrogen, hydrogen sulfide, phenols, etc.), ground and surface waters, removal from agricultural turnover of valuable land. Each thousand tons of underground mining is accompanied by the release to the surface of $110-150 \mathrm{~m}^{3}$ of rocks, a thousand tons of coal enrichment - by storing $100-120 \mathrm{~m}^{3}$ of rocks. The waste of coal enterprises causes the alienation of a significant amount of scarce land, pollution of groundwater, soil and air basin. In 2016, in the Kemerovo region there were 139 facilities for the storage of waste from coal-mining enterprises.

It should be noted that a significant part of the masses disturbed by mining is located in densely populated areas of the region, which directly reflects on the quality of life of the population.

Thus, damage to urban and agricultural zones only from damage to land resources includes the following components:

- damage as a result of violation of the requirements of the law when handling production and consumption waste;

- damage from violation of the requirements of legislation in the field of agricultural land;

- loss of profits from lost rent for the use of agricultural land;

- loss of profits due to lack of harvest.

\section{Results and Discussion}

It is rather difficult to calculate the damage from environmental pressure due to the changing methodological support and the difficulty of finding reliable information about the measurements taken.

As on January 1, 2018, the area of disturbed land amounted to 102129 thousand hectares, 95970 thousand hectares of which were disturbed during the development of mineral deposits, 3063 thousand hectares - by construction, and 2564 thousand - by the disposal of industrial and solid wastes. If we calculate the investments necessary for the restoration of these lands, we must count the real economic damage first:

\section{2,000 hectares $x 200,000$ rubles per hectare $=20.4$ billion rubles}

This amount is obtained based on the fact that the cost of reclamation of 1 hectare of land is 200 thousand rubles. An analysis of the ratio of the number of disturbed and re-cultivated lands shows that this damage is created not so much for the present as for the future economy. The value of damage will increase many times if the environmental and economic damage is considered taking into account the natural and economic importance of the soil, land resources and indexation coefficients. In this case, the standard value of the development of new land instead of rejected for non-agricultural land prices will increase to 1020 thousand rubles/ha, while the costs required for the restoration of disturbed land will be:

$$
\text { 102,000 hectares } x \text { 1,020,000 rubles }=104 \text { billion rubles. }
$$

The effectiveness of restoring the ecological functions of disturbed lands (or equal reduction of environmental damage) is determined by the degree of approximation of the biological 
productivity of disturbed lands to the former ones before the disturbance or closely located homogeneous biogeocenoses. A generalized criterion of the degree of restoration of ecological functions can be the total biological productivity, expressed as a percentage of control: low - up to $25 \%$; satisfactory $-25-50 \%$; sufficient $-50-75 \%$. Higher productivity $(>75 \%)$ is achieved with full restoration of the soil cover, capable of creating and regulating the complex interactions of the food, geochemical, water-air regimes and soil properties.

The current regulatory documents treat reclamation more widely than is practiced in the coal industry. In addition to forestry, there are pastures and hayfields, simply wooded areas of environmental protection, areas of recreation and sports, hunting grounds, construction sites, etc.

The total amount of environmental damage, calculated in accordance with the used methodology, amounted to a little over 1 trillion rubles in 2017. It should be noted that these are data without loss of the missed benefit for under-utilization of the territory and unreceived income from non-mining business activities. In 2017, all the regional enterprises invested about 3 billion rubles in environmental protection measures.

To compare mining incomes and environmental damage costs, let us calculate the potential revenue from the sale of all coal. The average price for Kuzbass coal (except coking) is 3000 rubles per ton, for coking coals - from 12500 rubles per ton to 25500 rubles per ton. We take the minimal price of coking coal at 10000 rubles / ton. Proceeds from the sale is potentially 1,650 trillion. rub.

Comparing the incomes with the environmental damage, it turns out that it is necessary to spend $64 \%$ of the incomes from the sale of coal produced in 2017 in Kuzbass to compensate for the damage.

Next, we assess the losses associated with the disposal of agricultural land. To do this, we turn to the methods of assessing the market value of agricultural land.

The basis for assessing the market value of agricultural land is based on general principles for assessing the market value of land plots, which are applied taking into account the specific features of agricultural production.

The valuation of the market value of land of this type can be carried out, as a rule, by the method of comparing sales, by the cost method and by the method of capitalization of land rent. The latter method is based on the principle of residual land productivity. Sources of land rent can be both its direct exploitation - the generation of income as a result of production activities, and the renting out.

The features that need to be considered when assessing the market value of agricultural land include the following [5]:

- the need to maintain soil fertility of agricultural land through the use of appropriate agricultural technology and compliance with certain requirements for methods of production (for example, compliance with the standards of grazing, the establishment of appropriate crop rotation systems, the introduction of a certain amount of fertilizer, etc.);

- direct dependence of the structure of agricultural land on the physical-and-geographical characteristics of the area (geomorphological, soil, hydrological, climatic and other features); - high risks of agricultural production due to Siberian climate factors and force majeure (droughts, floods, epizootics and other natural disasters);

- large influence on the amount of income received from agricultural production of market price fluctuations for food, fuel and lubricants, agricultural equipment; the seasonal cycles of agricultural production and market prices;

- lack of actual turnover of agricultural land, lack of significant investments in agricultural production; low population density in areas distant from large industrial centers;

- poor infrastructure development, in particular, paved roads, and poor development of the processing industry. 
When evaluating agricultural land using the method of comparing sales, a procedure similar to the assessment of the market value of built-up land plots is used, i.e., the selection of objects of analogue and a correction in their sale prices.

When applying the cost method to the cost of land, determined by the method of comparing sales, the cost of improvements in the amount of their replacement cost, taking into account accumulated depreciation, is added. Farm buildings and other structures that are the technological elements of agricultural production are considered as improvements [6].

In determining the market value of land by the method of capitalizing land rent, the value of land rent is calculated as the average value of the net operating income, determined taking into account the rotation of the main crops in the current rotation. Land rent can also be determined by income from lease payments for the use of agricultural land. Income can be determined in actually established prices for agricultural products, as well as in projected prices. When assessing pastures, income is determined on the basis of pasture productivity by fodder crops.

\section{Conclusion}

Our assessments concerned only the extent of harm to land and the handling of waste. It should be noted that the damage assessment caused by the disposal of industrial waste was conducted only for violations of one year, although previously accumulated waste continues to have a negative impact on the environment. All other types of damage to the environment (water resource, atmosphere), which have a significant impact on public health and the quality of human capital in the region, are also out of sight.

Meanwhile, investments in the environmental protection sector are at an extremely low level and tend to decrease.

Based on the foregoing, it is believed that it should:

1. Investing the reclamation projects need to be carried out not before, but after the formation of a technogenic landscape using the whole arsenal of modern methods and technologies, using the existing intellectual potential in this area, taking into account the social needs, due to losses of agricultural and forestry already paid by the company production.

2. Reclamation processes do not occur instantly, but over several years. Therefore, it is necessary to develop and legislate a single mechanism for the entire region to increase the interest of subsoil users in investing the remediation works.

\section{References}

1. L. Starikova, I. Trapeznikova // E3S Web Conf., 41, 02019 (2018)

2. Regional Statistic Service of Kuzbass. URL: http://kemerovostat.gks.ru

3. L. S. Sagdeev, I. S. Trapeznikova, Analysis of interrelations between indices of human development and unfavorable ecological situation (on the example of the Kemerovo region) (Eurasia, Barnaul, 2007)

4. L. S. Sagdeeva, The Impact of public health on the human resources of the region (Business Kuzbass, Kemerovo, 2011)

5. The Federal valuation standard "Valuation of real estate" (FVS \# 7) (Ministry of Economic Development of Russian Federation, Moscow, 2014)

6. L. M. Butler, Ecological component of economic valuation of real estate (MSU, Moscow, 2006) 